Preprints of the

Max Planck Institute for

Research on Collective Goods

Bonn 2008/11

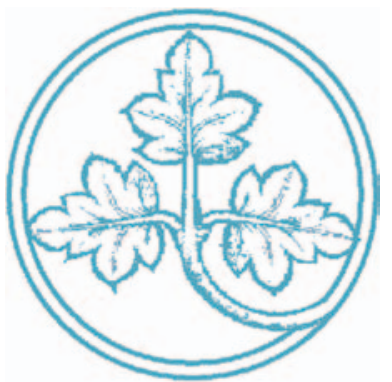

Corporate Governance and Incentive Contracts: Historical Evidence from a Legal Reform

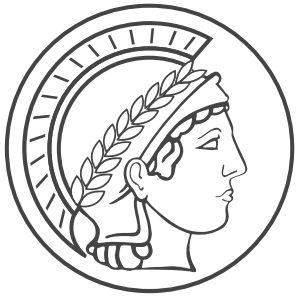




\title{
Corporate Governance and Incentive Contracts: Historical Evidence from a Legal Reform
}

\author{
Christian Bayer / Carsten Burhop
}

March 2008 


\title{
Corporate Governance and Incentive Contracts: Historical Evidence from a Legal Reform
}

\author{
by \\ Christian Bayer \\ IGIER - Università Commerciale Luigi Bocconi \\ Via Salasco 5, 20136 Milano, Italy \\ Email: christian.bayer@unibocconi.it \\ and \\ Carsten Burhop \\ Max Planck Institut zur Erforschung von Gemeinschaftsgütern \\ Kurt-Schumacher-Str. 10, 53113 Bonn, Germany \\ Email: burhop@coll.mpg.de
}

First version: 5 June 2003

This version: 31 March 2008

We would like to thank Martin Hellwig, Bengt Holmstrom, Kornelius Kraft, Michael Roos, Richard Tilly, Eugene White (our commentator at the 2007 ASSA meeting), participants of the RES Meeting 2004, the EEA Meeting 2004, the GEABA Meeting 2004, the EHS Annual Conference 2006, the German Clio 2006, the 14th IEHA Congress 2006, the ASSA Meeting 2007, and seminar participants at the University of Dortmund for helpful comments and suggestions. The authors would like to thank the Deutsche Forschungsgemeinschaft for financial support (grant no. BU 1805 / 2-1) and Marina Boland, Kathrin Datema, Eva große Kohorst, and Annika Petersen for assistance in collecting the data. A previous version of this paper was circulated under the title "A corporate governance reform as a natural experiment for incentive contracts" and was written while Christian Bayer was Jean Monnet Fellow at the European University Institute and Carsten Burhop was Research Fellow at the Center for Development Research, Bonn University. The financial support of these institutions in gratefully acknowledged. 


\title{
Corporate Governance and Incentive Contracts: Historical Evidence from a Legal Reform
}

\begin{abstract}
This paper proposes to exploit a reform in legal rules of corporate governance to identify contractual incentives from the correlation of executive pay and firm performance. In particular, we refer to a major shift in the legal and institutional environment, the reform of the German joint-stock companies act in 1884. We analyze a sample of executive pay for 46 firms for the years 1870 to 1911. In 1884, a law reform substantially enhanced corporate control, strengthened the monitoring incentives of shareholders, and reduced the discretionary power of executives in Germany. Pay-performance sensitivity decreased significantly after this reform. While executives received a bonus of about three to five per cent in profits before 1884, after the reform this parameter decreased to a profit share of about two per cent. At least the profit share that is eliminated by the reform must have been incentive pay before. This incentive mechanism was replaced by other elements of corporate governance.
\end{abstract}

JEL-Classification: G30, J33, N23

Keywords: pay-performance sensitivity, natural experiment, legal reform, corporate governance

\section{Introduction}

Providing the right incentives for corporate executives was and still is of great concern to shareholders. More than a century ago, lawyers lamented that a cozy frivolousness got a grip on many joint-stock companies. ${ }^{1}$ In a similar spirit, economic scholars highlighted the informational advantages that executives naturally had compared to shareholders. Moreover, they were pessimistic about the means and abilities of the shareholders to effectively monitor managers given their natural informational advantages. ${ }^{2}$ Under these circumstances, they argued in anticipation of modern economic theory, executives should receive monetary incentives to align their interests with the shareholders' aims. ${ }^{3}$

In the light of this basic economic insight, an optimal compensation package tames the selfinterest of the management such that shareholders' and management's interests align. Share-

1 „[...] so herrscht doch in vielen, namentlich neuen Aktiengesellschaften eine Atmosphäre des gemüthlichen Leichtsinns, der Bequemlichkeit, der Verschwendung“, Oechelhäuser (1878, pp 4).

2 [...] dass die Direktoren schon kraft ihrer besseren Kenntnis des Geschäfts, ihrer Vertrautheit mit allen Einzelheiten des verwickelten Geschäftsmechanismus eine natürliche Überlegenheit über die Aktionäre besitzen, diese aber dasjenige weder wissen noch wissen können, was sie unbedingt wissen müssten, um die Oberaufsicht und Leitung des Unternehmenswirksam durchführen zu können“, Petrazickij (1906, pp 152).

3 „Was zuerst die Direktoren betriff, so wird sich nichts dagegen sagen lassen, dass sie, als Entschädigung wie als Sporn, außer dem Gehalt auch eine Tantieme erhalten." Oechelhäuser (1878, p 75). 
holders are not willing to provide huge pay checks to a shirking management, but they are willing to provide compensation for managerial work for good performance. A standard approach to measure whether remuneration packages are justified by good performance is the pay-performance correlation. ${ }^{4}$ Although this correlation is important as a measure, it is not clear that incentive pay is the only reason for high correlations. In particular, pay and performance may be linked by various factors unrelated to managerial effort, e.g., job design, differences in managerial ability, or cyclical shifts in demand for managerial services.

However, these latter types of correlation do not reflect an incentive phenomenon; they will be also present in a world with complete and perfect information. In other words, to analyze contracts empirically, we have to separate the contracted link of pay and performance from the ex post correlation of pay and performance as a result of market outcome. ${ }^{5}$ We propose to exploit a major shift in the legal and institutional environment to assist identification. ${ }^{6}$

Of particular interest for our research strategy are shifts that alter the contractual relation of pay and performance, but have no significant effect on the correlations between pay and performance that result from other market forces. Such shifts could be legal reforms that do not affect the abilities or other fixed characteristics of a manager, that are performance-relevant and observable to the principal, but not to the econometrician. This makes improvements in legal (minimum) standards of corporate governance particularly promising as object of study. Such reforms enrich the set of means of corporate control that principals can use, who can redesign the tasks of executives and then adjust monetary incentives. Therefore, from a theoretical point of view, they have clear-cut implications for managerial contracts and as such they can serve as a test for the incentive theory of contracts. ${ }^{7}$

Yet, it is rare to observe a major change of legal institutions that qualifies for this testing strategy. First of all, the legal reform must lead to unambiguous predictions for the parameters of contracts between principals and agents. Typically, only a few substantial reforms thus qualify. Second, we need to observe the contractual relationship for a prolonged period of time before and after the reform. For example, the Sarbanes-Oxley-Act of 2002 may well qualify as a major reform. ${ }^{8}$ However, for our testing strategy, the time period after the reform

4 See Murphy (1999) for an overview of the literature on executive compensation; and Prendergast (1999) as well as Lazear (2000) for more general reviews of incentive contracts in firms.

5 For example, Himmelberg and Hubbard (2000) as well as Grossmann (2003) argue that generalequilibrium effects induce some correlation between performance and pay even without any strategic considerations when able managers are scarce. Additionally, better-qualified managers will work for firms that highly reward performance. Thus, incentive contracts become a selection device and increase performance, but do not induce managers to exert more effort (Lazear 1986).

6 For example, Conyon (1997) and Core et al. (1999) find that changes in corporate governance significantly influence the level of managerial compensation.

$7 \quad$ Holmstrom and Milgrom (1991) highlight that job design - e.g., the discretionary power of executives and incentive contracts should be analyzed jointly. More specifically, a reduction of the discretionary power of the executive should go hand in hand with a reduction of incentives.

8 Goldman and Slezak (2006) analyze theoretically the impact of the Sarbanes-Oxley Act on both the misrepresentation of firm performance and managerial contracts and find that the Sarbanes-Oxley Act should have an important effect on both. Moreover, Chhaochharia and Grinstein (2007), Litvak (2007), and Win- 
was too short to allow an understanding of its long-term implications. ${ }^{9}$ In short: our testing strategy needs a historical perspective. This brings up a third restriction on the choice of a legal reform as an identification instrument. Both before and after the reform, the database of the analysis has to be sound; and it will typically be based on accounting and stock market data.

This leads us to consider data from the German Empire before World War I. Legal minimum standards for the publication of company accounts and accounting rules were introduced in Germany earlier (in 1861) than in Britain (1900/06) or in the US (1934). Furthermore, there was a legal reform in Germany in 1884 that primarily aimed at a new regulation of initial public offerings (IPOs), but that substantially reshaped corporate law. This reform can be expected to have had a substantial impact on contractual relationships between managers and owners of firms.

Because of this, we have sampled a data base that allows us to analyze the impact of the 1884 reform on managerial contracts and therefore allows us to test for the incentive character of the performance and pay correlation. Our data comprises information on firm-level accounting, stock market, and management compensation for 37 manufacturing companies and nine banks for the time period between 1870 and 1911.

We observe executive compensation to have been significantly sensitive to firm performance within manufacturing firms and banks for both the periods of 1870 to 1884 and of 1885 to 1911. However, after the 1884 reform, managerial contracts were different and the pay performance sensitivity decreased. Before 1884 each manager of a manufacturing firm (bank) received a profit share of about 4.0-4.7 per cent (3.2 per cent for banks), while after the reform, the profit share of a manager decreased to 1.2-1.7 per cent in the manufacturing sector and 1.8 per cent in the banking sector. This means that the 1884 legal reform reduced the sensitivity of executive pay to performance by about two-thirds for manufacturing firms and by about one-third for banks. This result proves robust with respect to different estimation techniques, sample splits, and control variables.

The 1884 reform unambiguously improved the shareholders' ability to control managers directly. Consequently, we can interpret the change in the pay-performance sensitivity as a

toki (2007) investigate the impact of the Sarbanes-Oxley Act on the stock market value of firms. They figure out that the reform has - on average - a negative impact on the stock market value of the firms, but that the effects differ substantially in the cross-section of firms. A more general overview is provided by Cheffins (2001), who compares recent trends in the legal foundations of executive compensation in the U.S., the U.K., and Germany.

9 The 1992 Cadbury reforms in the UK might serve as a testing ground. Yet, these reforms were voluntary and one starting point of the inquiry of the Cadbury committee was executive compensation itself. For both reasons, it does not qualify as a natural experiment due to the lack of exogeneity. This might be the reason why Girma et al. (2007) find the reforms to have little effect on the pay and performance correlation. 
lower bound for the extent to which incentive pay was used before the reform. Monetary incentives were replaced by other corporate governance mechanisms. ${ }^{10}$

The remainder of the paper is organized as follows: Section 2 reviews the related literature and discusses the theoretical ideas upon which we base our empirical analysis. Section 3 provides a summary of the historical setting from which we take our data. It particularly focuses on the legal reform that forms the key ingredient in our identification strategy. Section 4 describes our data. Section 5 presents the results of our empirical analysis, and finally Section 6 concludes.

\section{Literature, Theory, and Econometric Background}

Earlier empirical studies of managerial incentive pay concentrated on the reduced form relation of pay and performance. In particular, they focused on the remuneration of top executives of publicly traded companies. Jensen and Murphy (1990) reported in their seminal article that the compensation of CEOs increases by $\$ 3.25$ per $\$ 1,000$ increase in shareholders' wealth. This has been perceived as providing weak incentives for executives.

Since many factors shape the contracts, it is hard to determine what would constitute optimal pay-performance sensitivity (see Garen, 1994). In any case, Hall and Liebmann (1998) find an increase in the pay-performance sensitivity for the late 1990s. In between these two seminal papers, a large strand of research was triggered by the findings of Jensen and Murphy (1990). ${ }^{11}$

More recently, a number of authors have emphasized potential problems of identification that may cast some doubts on this first generation of empirical articles on pay for performance. A correlation of pay and performance can result from a number of other factors besides managerial contracts which reward performance to induce effort. For example, good managers may be paid better simply because they deterministically perform better. In a similar fashion, Himmelberg and Hubbard (2000) argue that business or sectoral cycles will induce a pay and performance correlation that is unrelated to incentives. The correlation only reflects that demand for managerial services rises during booms, but the supply of managers is fixed in the short run.

10 Yet, the 1884 corporate law reform also improved accounting standards. In particular, the publication of a profit-and-loss statement became compulsory after the reform. This improves the quality of the signal received by the principal. In turn, principals should increase incentives (Holstrom and Milgrom 1991, p 42). However, this effect should be minimal in our case, since we use only data from firms publishing profitand-loss statements before the legal reform.

11 Following Jensen and Murphy’s approach, Schwalbach and Graßhoff (1997) and Kraft and Niederprüm (1999a, 1999b) investigate the link of managerial remuneration and company performance for Germany. Like Jensen and Murphy's findings for the US, they also find rather weak pay-performance sensitivity. General overviews of the executive remuneration and corporate governance literature are given by Core et al. (2003), Murphy (1999), Hart (1995), Tirole (2001), and Shleifer and Vishny (1997). 
To achieve identification nonetheless, a typical estimation strategy has since consisted in the use of difference(-in-difference) methods. For instance, Baker and Hall (2004) look at the difference in the compensation of managers of large and small firms. Elston and Goldberg (2003) analyze the influence of ownership structure on the pay-performance relation; Aggraval and Samwick (1999) analyze the impact of differences in risk; and Cunat and Guadalupe (2005) use a shift in exchange rates as a quasi-natural experiment to analyze the impact of an increase in the competitiveness of a market on managerial compensation schemes. Most closely related to our approach is the paper by Talley and Johnsen (2004), which analyzes the interaction of corporate governance, executive compensation, and securities litigation. They provide a detailed model of this interaction and find that corporate governance serves as a substitute for incentive pay, both empirically and theoretically. The changes in corporate governance that Talley and Johnsen (2004) analyze, however, are mostly endogenously adopted; and this does not really allow them to use the changes for identification. ${ }^{12}$

Our point of departure is similar. We start with the ability to substitute monetary incentives by other means of corporate governance. Our aim, however, is to focus on identification and we employ an exogenous change in legal institutions as an identification device. Specifically, we investigate how the legal reform of the joint-stock-companies act in 1884 in Germany changed the pay-performance sensitivity of managerial contracts in the manufacturing and in the banking sector.

Corporate and private law can be understood as the ground upon which principals and agents base their contracts. It defines the set of enforceable agreements; it sets the rules of corporate control and hence determines a principal's information; and last but not least, it restricts an agent's set of possible and legal actions. The 1884 corporate law reform influenced these three areas of corporate governance. For example, stricter accounting rules restricted the set of possible actions of the agent (e.g., 'cooking the books'); it increased the liability of the agent if she presented incorrect figures in the accounts; and it improved the set of information available to investors (e.g., whether they received a profit and loss statement).

In short, any shift in the legal rules that define corporate governance can be expected to influence the agent's contract. At the same time, legal reforms of corporate governance will typically not affect the abilities or other fixed characteristics of a manager which are performance-relevant and observable to the principal, but not to the econometrician. Therefore, to identify this we can exploit a shift in legal rules. The legal reform that we look at may be summarized as one that reduced the discretionary power and the set of possible tasks for executives, so that we can expect the use of incentive pay to be decreased by the reform (see the next section).

12 Joskow et al. (1996) also analyze the effects of regulation on incentive pay. Yet their focus is on the political influence on compensation packages rather than on structural identification. 
Based on this idea, an identification strategy may be illustrated in the following formal way. Suppose that

$$
\text { (1) } \mathrm{w}_{\mathrm{i}, \mathrm{t}}=\alpha_{0}+\beta \pi_{\mathrm{i}, \mathrm{t}}+\alpha_{\mathrm{i}}+\mathrm{u}_{\mathrm{i}, \mathrm{t}}
$$

defines the employment contract of a manager, where $\mathrm{w}_{\mathrm{i}, \mathrm{t}}$ denotes the compensation of manager $i$ at time t. The compensation package is linear and depends on the published profit $\pi_{\mathrm{i}, \mathrm{t}}$ of the firm where manager $i$ is employed in period $t$, with the pay-performance sensitivity $\beta$ plus the random components $\alpha_{i}$ and $u_{i, t}$. Here, $\alpha_{i}$ captures all fixed characteristics of the managerfirm match, which also includes all the unobserved characteristics of the manager.

The most straightforward empirical approach would be a direct estimation of (1) by means of some least-squares estimator. However, this approach will not necessarily identify incentives $\beta$, because profits $\pi_{i, t}$ and the error term $\left(\alpha_{i}+u_{i, t}\right)$ may be correlated, as outlined before. Nonetheless, if $\beta$ varies with changes in legal institutions, we can still identify at least the change in $\beta$ by considering two sub-periods, period $\tau_{0}$ and $\tau_{1}$, for which $\beta$ differs. For each period $\tau_{\mathrm{j}}$ the simple OLS estimator asymptotically converges to

$$
p \lim _{n \rightarrow \infty} \hat{\beta} \tau, j(n)=\beta_{\tau, j}+\operatorname{corr}\left(\pi_{i, t}, u_{i, t}+\alpha_{i}\right) .
$$

The difference of the estimates $\beta \tau 1-\beta \tau 0$ is not biased if corr $\left(\pi_{i t}, u_{i t}+\alpha_{i}\right)$ is constant for both sub-periods. This is what we can expect in our case. The correlation captures the relationship of individual characteristics and the performance or business cycle effects, for example, most likely not influenced by the legal reform in 1884 .

As a result, the difference $\hat{\beta} \tau 1-\hat{\beta} \tau 0$ is estimated without bias, i.e.,

$$
\hat{\beta} \tau 1-\hat{\beta} \tau 0=\beta_{\tau 1}-\beta_{\tau 0}
$$

For this reason, this estimated difference can serve as a lower bound of the monetary incentives set in the manager's contract itself. No rational compensation will punish good performance, so that $\beta_{\tau \mathrm{j}}$ is non-negative and

$$
\beta_{\tau 1} \geq \beta_{\tau 1}-\beta_{\tau 0}=\hat{\beta} \tau 1-\hat{\beta} \tau 0
$$

Making use of these considerations leads from equation (1) to our estimation equation

(2) $\mathrm{w}_{\mathrm{i}, \mathrm{t}}=\alpha_{0}+\beta_{\tau 0} \pi_{\mathrm{i}, \mathrm{t}}+\left.\left(\beta_{\tau 0}-\beta_{\tau 1}\right) \pi_{\mathrm{i}, \mathrm{t}}\right|_{\mathrm{t} \in \tau 1}+\gamma \mathrm{x}_{\mathrm{i}, \mathrm{t}}+\alpha_{\mathrm{i}}+\mathrm{u}_{\mathrm{i}, \mathrm{t}} \cdot$

In this equation, $\left.\right|_{t \varepsilon \tau 1}$ denotes an indicator function that takes the value 1 after the reform, and is zero otherwise. The vector $x_{i, t}$ represents other covariates that could influence bonus payments. On a more technical side, censoring complicates the analysis to a certain extent: While in theory contracts could bind agents to pay a penalty for underperformance, most legal sys- 
tems would rule out or at least limit such contracts. In practice we thus need a non-negativity constraint for bonus payments into account. Hence, the managerial compensation $\mathrm{w}_{\mathrm{i}, \mathrm{t}}$ is always positive, which means we have to estimate equation (2) by a random-effects tobit estimator. In fact, in a significant number of observations in our data, we see zero bonus payments, highlighting that the theoretical warrant is empirically important. Besides the mass of zero bonus payments precludes that we specify equation (1) log-linear instead of linear.

\section{Historical background}

Germany's financial history of the 1870s and 1880s is shaped by the repercussions of the Gründerzeit (foundation or promotion period). Between 1871 and 1873, the time immediately after the 1871 foundation of the German Empire, 843 joint-stock companies were founded in Germany. Out of these, at least 442 were quoted on the stock market. This period was followed by the Gründerkrise (foundation crisis) of 1873-79, during which several hundred of the new joint-stock companies failed and 225 companies were de-listed from the stock market. Classical accounts by contemporaries as well as recent scholarship relate the boom of 1871-73 to the introduction of the free incorporation of joint-stock companies in Germany during 1870, and to a number of accompanying economic and psychological factors, e.g., the optimistic public mood after the foundation of the German Empire and the substantial indemnity paid by France after the German-French War of 1870-71 (Baltzer, 2007).

Contemporary observers at the time emphasized that the extreme volatility of the market for IPOs would have negative long-term consequences for the German economy. Of the hundreds of joint-stock companies founded in the boom years, several hundred failed during the following few years. This was perceived as a deep economic crisis, which resulted in the break-up of many corporations. The latter, in particular, was a new phenomenon for contemporaries: before 1870, the foundation of a joint-stock company had only been possible in most German states with a governmental concession. Such a concession was often difficult to obtain, and the number of joint-stock companies in Germany was very small. This changed in 1870, when the free incorporation of joint-stock companies was first allowed. ${ }^{13}$

The boom-and-bust cycle of the German IPO market of the early 1870s encouraged emotional debates in German parliament, the financial press, and between academics. ${ }^{14}$ One major component of the criticized 1870 law was the switch from a concession to a normative system of incorporation. Before the 1870 reform act, a governmental concession was necessary in most

13 This means also that from 1871 onwards, corporate law was a federal law and uniform for the German Empire. This compares to the US, where free incorporation was introduced first in Connecticut in 1837. Since then, the regulation of corporations in the US, which historically has been a state matter, has led to a more laissez-faire treatment of standards (Grandy, 1989). In Britain, free incorporation for all business sectors was finally introduced in 1856 (Taylor, 2006, p 135).

14 For example, both Wilhelm Oechelhaeuser (1876) - a German parliamentarian, law professor, and expert on joint-stock companies - and Ernst Engel (1875) - president of the Prussian statistical office - point to the importance of the 1870 legal reform and the low moral standards of incorporators. 
German states to found a joint-stock company, whereas after the liberalization, basically every citizen could found such a company. Furthermore, the new law abolished the extensive audit of foundation projects by public authorities and the state supervision of joint-stock companies. Instead, company supervision was handed over to a shareholder body, the supervisory board (Aufsichtsrat), see, e.g., Renaud (1875) or Gareis (1880) for textbook treatments of Germany's corporate law in this period. Thus, the 1870 reform established the German system of corporate control of today, which differs from the UK and US systems (see Fohlin, 2007, and Fear and Kobrak, 2006, for details).

The reform introduced a two-tier board system, a system of an executive and a supervisory board. The executive board (Vorstand) is responsible for the daily management of the firm, whereas the supervisory board (Aufsichtsrat) monitors the executive board and takes part in strategic decision-making. Therefore, it is comparable to the function of non-executive directors in the US and UK systems. Part of the responsibility of the supervisory board was to negotiate and close the executive contracts. The typical executive contract specified a share of profits that this executive would be entitled to (Burhop, 2004, 2005).

According to the 1870 law, the supervisory board was a permanent board of shareholders that was to monitor the executive board. It had to report on this activity at the annual meeting of shareholders (§ 225 ADHGB; ${ }^{15}$ Renaud 1875, pp 626; Gareis 1880, pp 214). However, the shareholders' influence on the composition of the supervisory board could be restricted. Only the first supervisory board had to be elected by a shareholder meeting. Thereafter, the supervisory board could co-opt further members at will without the actual shareholders taking part in this decision, i.e., supervisory board members were not necessarily elected by the shareholders but by the other members of the supervisory board (Renaud 1875, p 628). The first shareholder meeting was regularly held before the firm was quoted on the stock exchange, and thus the founders effectively appointed the first supervisory board. Therefore, the actual shareholders were not necessarily represented at the supervisory board, a momentous restriction of monitoring rights.

The executive board, the Vorstand, was responsible for the daily management of the firm ( $\S \S$ 209, 227 ADHGB; Renaud 1875, pp 524; Gareis 1880, pp 210, Makower 1877, p 224). However, nearly all decision rights could be delegated from the executive board to the supervisory board in the corporate charter. If this was done, nobody could be held legally accountable for corporate activities, since the law only stipulated a criminal offence for the executive board. Even intentional misbehavior had no legal consequences then, because - as mentioned above - at most members of the executive board could be punished for intent.

The only way for shareholders to exercise their rights was to vote at the annual general meeting, the Generalversammlung (§£ 209, 224 ADHGB; Renaud 1875, pp 458; Gareis 1880, pp

15 ADHGB = Allgemeines deutsches Handelsgesetzbuch (General German commercial law). 
207). The legal default was that every share had one vote at this meeting. However, voting and participation rights could be restricted by the company's charter. For example, the number of votes of each shareholder could be limited, or the number of shares needed to cast one vote could be larger than one. The first regulation restricted the voting power of block holders, whereas the latter one annulled the voting rights of small holders.

Additionally, information rights of shareholders were weak under the 1870 legislation. Only the publication of a balance sheet was stipulated, but it was neither necessary to release a profit-loss statement nor to release a management report. Nonetheless, many corporations did so. For these reports and the balance sheets, the valuation of assets was regulated, but some room for creative accounting remained.

Altogether, corporate governance under the 1870 law was insufficient: the voting and participation rights of the shareholders at the annual meeting could be restricted; the supervisory board was not necessarily elected by shareholders; the power-sharing was not clear-cut between the weakly accountable executive board and the non-accountable supervisory board; shareholders were not necessarily well informed.

Nonetheless, the debate about the deficits of the 1870 act centered on problems of IPOs. ${ }^{16}$ As a reaction, a new company law was enacted in 1884. The focus of the reform act was on incorporation (see Deutscher Reichstag, 1884); nonetheless, corporate governance standards were raised. The 1884 joint-stock companies act significantly improved the monitoring and information rights of shareholders, and it broadened the accountability of the two boards.

After 1884, every shareholder had voting and participation rights at the annual meeting, but there was still a restriction on the maximum number of votes of a shareholder under the 1884 law ( $\S \S 190,221$ ADHGB). With the new legislation, every member of the supervisory board had to be elected by the shareholders ( $\S \S 191,224$ ADHGB). Moreover, non-shareholders, i.e., professional monitors like bankers, could be elected to the supervisory board after 1884 . Finally, a clear and strict legal separation between the supervisory and the executive board was established ( $\S \S 192,225 a$ ADHGB). The executive board was responsible for the daily management and strategic decisions. The supervisory board's main duty became monitoring, but it maintained a right to participate in strategic decision-making. In fact, the supervisory board became legally obliged to monitor the executive board. If they failed to do so, they were after 1884 subject to damages and securities litigation.

Turning to information rights, the publication of a balance sheet, of a profit-loss statement, and of a management report became compulsory with the new 1884 legislation. Moreover,

16 See, e.g., Glagau (1876) for a polemic account, or Deutscher Reichstag (1873) for an early parliamentary discussion. The motives given by the Parliamentary Commission preparing the new corporate law starts with a discussion of the general need for reform (pp. 236-246), followed by discussions about the character of shares (pp. 246-260), the foundation of a company (pp. 261-281), the issuance of equity (pp. 282286), the relationship between boards and shareholders after the foundation (pp. 286-301), and accounting standards (pp. 301-306). 
asset valuation was more strongly restricted and the scope for creative accounting declined substantially. Altogether, the extent and quality of information rights improved after 1884 .

Also, the threat of punishment in case of executive's misbehavior was altered by the reform (Deutscher Reichstag 1884, pp 343). First of all, the new law clarified that the intentional misbehavior of executives or supervisory board members was a criminal offence, which was to be punished by imprisonment and a fine (§ 249 ADHGB). In particular, the maximum penalty for intentionally misreporting accounting figures was increased from three months imprisonment and a 3,000 Mark fine to one year imprisonment and a 20,000-Mark fine (§ 249a ADHGB). ${ }^{17}$

Although the effectiveness of the 1884 act was questioned by some contemporaries, this discussion focused more on possible extensions of the reform than on the general direction of the reform itself (Warschauer 1902; Philippovich 1909). In general, the reform was perceived as an improvement of corporate control and corporate governance (Hessberger 1889, p 57). In particular, the discretionary power of managers declined and misbehavior was more costly to managers after 1884; this can be expected to have had a substantial influence on the economic relationship between principals and agents.

What is important for our research question and strategy is to keep in mind that while the reform in 1884 was intended to solve problems of incorporation, it also had strong and important implications for corporate governance. The reform was not motivated by excessive management compensation. In fact, the legislators did not consider existing compensation schemes or problems with those in the run-up debate for the 1884 reform at any point, as the protocols of the debates in the Prussian and national parliaments (see, e.g., Deutscher Reichstag, 1873, pp 213) and the commission report (Deutscher Reichstag, 1884) show. ${ }^{18}$ Outside the parliament, there was some debate about the level of supervisory board compensation. Yet executive board compensation was not considered problematic (Oechelshaeuser, 1878, p 7576). Therefore the reform qualifies as a natural experiment for compensation schemes. The improvement of corporate control can be expected to have influenced compensation schemes offered to managers. At the same time, it is not a result of management compensation that paid out too large of a share of profits to managers.

17 These figures compare to an annual per capita NNP of roughly 400 Mark in 1880 or a typical compensation for executive board members in manufacturing of roughly 20,000 Mark. Legislators defeated a higher maximum penalty since this would immoderately weaken monitoring incentives for shareholders.

18 The only remark in the whole motivations and reasons for the 1884 reform that comes close to a debate on compensation schemes is a debate on the compulsory shareholding of executives. The act finally decided against such a compulsory requirement, so as not to interfere with the optimal allocation of managers to companies (Deutscher Reichstag, 1884, p 332). Since the spring of 1873, the topic of corporate law reform was debated in the German parliament (see, e.g., Deutscher Reichstag, 1873, pp 213). The discussion of the 1870s is summarised in the motivations and reasons for the 1884 reform act (Deutscher Reichstag, 1884). 


\section{Data Description}

\subsection{Sources}

Our database is derived from a number of sources for accounting, stock market, and executive data on German corporations between 1870 and 1911. Our final sample consists of 37 manufacturing corporations and nine banks. The firms were selected to represent the distribution of long-living firms listed at the Berlin stock exchange in 1900. We focus on long-living firms since we need to observe them for several years before, as well as after, the legal reform in 1884. This implies that the population of firms from which we can draw our sample is small. We focus on manufacturing and banking, as these sectors were neither heavily regulated (unlike public services) nor significantly cartelized (unlike mining).

There was a total of 387 listed corporations in Germany in 1880. Of these, only 142 were manufacturing firms (van der Borght, 1883). Since not all corporations listed in 1880 survived for a long period thereafter, the population of firms usable for our research is even smaller. Correspondingly, our sample covers about one quarter of the entire population of listed manufacturing corporations in 1880, and a significantly larger fraction of long-living firms.

The restriction on long-living firms - though necessary for our research strategy - biases our sample towards successful corporations. Moreover, we only include corporations which published all necessary information already before the implementation of the 1884 law reform. More specifically, all firms in our sample voluntarily reported profit-and-loss statements. This specific sample selection has an important consequence for the interpretation of our results. In general, those companies with good corporate governance prior to the reform can be expected to be less affected. Consequently, the measured effect of the reform for our sample should provid a lower bound for the entire population of firms.

The main data source is "Saling's Börsenpapiere", an annual stock market publication for Germany, which was occasionally published before 1880 and was published annually from that year onwards until World War I. This widely circulated handbook was targeted towards investors and bankers. It contained accounting and stock market data for all companies quoted at the Berlin stock exchange. In addition, it provided information about the company's charter that was relevant to potential investors, e.g., information about voting rights and the distribution of profits. Finally, it reported the names of the executive board members. Today this rich source is an important database for quantitative economic history (e.g., Tilly, 1989; Edwards and Ogilive, 1996; Fohlin, 1998).

To make this data usable, we partly rely on existing digitalized data sets collected from "Saling's Börsenpapier", and we digitalized additional data ourselves. These additional data are, unless otherwise stated, taken from “Saling's Börsenpapiere”. We take data collected by Rettig (1978) from manufacturing, mining, and non-financial service firms, and data collected by Bittner (2005) from mining and manufacturing. Rettig (1978) structured his sample so as 
to represent the size and geographical variation of firms reported in "Saling's Börsenpapiere" in 1900. Bittner (2005) adds some manufacturing and mining firms to Rettig's sample, using the same criterion. Rettig (1978) and Bittner (2005) focus on accounting and stock market data. We supplement their data sets with information about bonus payments (Tantiemen) to executive and supervisory board members. In addition, we collected the names and tenure of each executive. Moreover, we collected information from the company charters for all firms for the years 1870 until 1911. In particular, we investigated the rules of the company charters when it came to voting rights and profit distribution.

Rules of profit distribution are particularly important for the construction of our final data. Most firms (77 per cent) announced a minimum dividend of four to six per cent of the paid-up share capital as a guaranteed dividend. Only profits above this threshold level determine bonus payments to executives. Therefore, our profit measure is the accounting profit less the announced minimum performance. We call this variable "excess profits". While inspection of actual contracts leads us to consider that "excess profits" are the relevant performance measure, this choice has a positive side effect. "Excess profits" is unlike book profits less subject to changes in the financing mix of the firm. It relates closely to a performance measure like earnings before interest. Yet unlike the latter it includes performance in the search for sources of external debt finance. Most importantly it is the measure of performance actual contracts referred to (Burhop, 2004, 2005).

The data sets provided by Rettig (1978) and Bittner (2005) start in 1880. Given that we want to analyze the impact of a reform in 1884, it is necessary to prolong Rettig's and Bittner's sample backwards from 1880 until 1870. If the company was founded after 1870, we obtain all data back until it was incorporated, if available. The relevant accounting, stock market, and executive data for the 1870s were collected from the few published issues of „Saling's Börsenpapiere“ and from the "Berliner Börsenzeitung”, Germany’s leading financial daily at the time. ${ }^{19}$

Furthermore, we added some banks to the sample, which were neglected by Rettig (1978) and Bittner (2005). The relevant data were collected from two secondary sources. Bosenick (1912) presents accounting and stock market data for the nine largest German banks for the years 1871-1910. We augment Bosenick's data with information on board membership reported by Reitmayer (1999); he provides this data for the years 1871-1913.

19 “Saling’s Börsenpapiere“ are available for 1870, 1873, 1875, and 1878. For the years in between, we have to rely on the "Berliner Börsenzeitung" where many corporations, but not all, published accounts. In addition, we checked the "Norddeutsche Allgemeine Zeitung”, Germany’s leading political daily, for additional information. Yet, no further information was published in this newspaper. The few corporations for which we have data in "Saling's Börsenpapiere", but not in "Berliner Börsenzeitung", are typically corporations with a marginal shareholder located outside Berlin. While these few corporations differ in their regional characteristics, they are not necessarily smaller or larger, nor more or less profitable. 
While most data items could be used as reported in the sources, our main variable of interest, i.e., bonus payments to executives, had to be reconstructed in a few cases. Some firms report only the bonus payment to both boards, the executive and supervisory board, as a whole. Since the bonus payments to the supervisory board were governed by a rule that was stated in the company's charter, we could reconstruct the bonus payment to the supervisory board on this basis. The bonus paid to the executive board was then calculated as the residual of the bonus to the two boards. Only information about bonus payments to the executive board is used in the regressions in Section 5.We do not observe base salary (fixed payments) of board members. Typically these fixed payments were negotiated and contracted upon for a 5-year period. They can be thought of as the element of compensation that rewards (known) managerial quality and long-term performance. Bonuses on the other hand can be thought of as a reward to managerial effort and performance in the short run.

From our initial sample of 88 corporations, we removed all companies that were active in non-financial services (nine corporations), or mining (30 corporations, because these industries were either regulated by the government (see Milward, 2004) or cartelized (see Peters, 1989) ${ }^{20}$ In addition, we removed three manufacturing firms, which do not report profits or the number of executives. Moreover, we removed 56 outliers where excess profits (i.e., profits in excess of the benchmark dividend stated in the company's charter) or bonus payments fall outside a two-standard deviations interval around their firm-specific mean values. ${ }^{21}$ The final sample consists of 46 corporations, 37 from manufacturing and nine banks, with a total of 1,140 observations, making an average of 24.9 years per firm.

\subsection{Data Quality}

For the US and Britain, the quality of historical accounting data is known to be problematic, since accounting principles and coded standards developed mostly during the $20^{\text {th }}$ century. By contrast, most of today's German system of accounting rules and its legal codification was developed during the second half of the $19^{\text {th }}$ century.

British companies limited by shares had to publish annual balance sheets only after 1900. Accounting standards were introduced in 1906. Nonetheless, accounts were generally inspected by auditors before that date (Matthews et al., 1997).

In the US, there were few states where disclosure requirements were introduced before World War I. The first state to introduce compulsory disclosure was Massachusetts, in 1903; here all other incorporation standards were comparatively high, too. However, it also meant that most companies chose to incorporate in other states, e.g., Delaware and New Jersey (Grandy,

20 Joskow et al. (1996) show that public regulation significantly alters compensation schemes. Moreover, Cunat and Guadalupe (2005) use an unexpected shift in competition as a natural experiment to identify the incentive component of managerial compensation.

21 Using +/- 3 standard deviations as outlier correction did not alter the results; see appendix for the referee. 
1989). To counteract the resulting problem of low information quality, in 1900 the New York Stock Exchange attempted to introduce compulsory publicity for listed companies. Nevertheless, the stock exchange was not very successful at enforcing its new regulation, and some firms preferred de-listing over disclosure. Moreover, while the New York Stock Exchange introduced disclosure, it did not enforce accounting standards (Baskin, 1988).

The overall picture differs substantially for Germany. In the $19^{\text {th }}$ century, German shareholders and the general public were much better informed about the financial situation of companies than their British or American counterparts. As early as 1861, it had become compulsory in Germany to publish an annual balance sheet, and minimum accounting standards were introduced. The publication of an annual profit-and-loss statement was prescribed from 1884 onwards, but many corporations published profit-and-loss statements before that date. Moreover, accounting standards were clear and undisputed and nearly of the same level as accounting standards in modern Germany (Fear and Kobrak, 2006). The general acceptance of accounting standards may, for example, be judged by the number of court cases regarding accounts. Between 1871 and 1913, only twelve lawsuits concerned with disputes over accounting (rules) were decided at the Imperial High Court (Reichsoberhandelsgericht, from 1880 Reichsgericht), the highest German civil court. ${ }^{22}$

\subsection{Descriptive Statistics}

Table 1 presents descriptive statistics for our data set. The sample period runs from 1870 to 1911 and contains 1,140 observations. Of these, 804 observations are from manufacturing firms, and 336 are from banks. Our analysis focuses on the manufacturing sample, using banks primarily for comparison. 
Table 1: Descriptive Statistics for the full sample 1870-1911

\begin{tabular}{|c|c|c|c|c|c|c|}
\hline & \multicolumn{2}{|c|}{ Manufacturing } & \multicolumn{2}{|c|}{ Banks } & \multicolumn{2}{|c|}{ Single-Executive } \\
\hline & Mean & Std.dev. & Mean & Std.dev. & Mean & Std.dev. \\
\hline $\begin{array}{c}\text { Total fixed asset (in million } \\
\text { Mark) }\end{array}$ & 4.54 & 5.06 & n.a. & n.a. & 3.49 & 2.35 \\
\hline $\begin{array}{l}\text { Stock-market value (in million } \\
\text { Mark) }\end{array}$ & 7.28 & 8.61 & 122.07 & 104.12 & 5.22 & 4.28 \\
\hline Share in debt of total assets & 0.34 & 0.15 & n.a. & n.a. & 0.27 & 0.15 \\
\hline Tobin's Q & 1.20 & 0.39 & n.a. & n.a. & 1.12 & 0.38 \\
\hline $\begin{array}{l}\text { Accounting Profits (in 1,000 } \\
\text { Mark) }\end{array}$ & 502.56 & 530.99 & $7,873.69$ & $7,103.04$ & 376.79 & 347.39 \\
\hline Excess Profits (in 1,000 Mark) & 298.20 & 357.36 & $3,740.59$ & $4,636.77$ & 206.29 & 255.27 \\
\hline $\begin{array}{c}\text { Bonus per executive (in 1,000 } \\
\text { Mark) }\end{array}$ & 11.90 & 15.57 & 145.34 & 145.14 & 15.04 & 17.26 \\
\hline Number of executives & 1.93 & 1.04 & 4.79 & 1.89 & 1.00 & 0.00 \\
\hline Number of observation & & & & & & \\
\hline
\end{tabular}

Sources: see Text, Section 4.1.

Firm size is measured by the value of fixed assets and the firm's stock-market value. ${ }^{23}$ On average, manufacturing firms had total fixed assets of about 4.5 million Mark and a stockmarket value of about 7.3 million Mark. Tobin's Q is approximately 1.2 on average, but it varies substantially. ${ }^{24}$ Furthermore, we include the debt ratio, i.e., debt over total assets, as a proxy for the dependence of manufacturing firms on external finance. Firms relying more on external finance can be expected to be monitored more closely by debt holders. Hence, they may offer different types of contracts to their managers. The average debt ratio is 34 per cent; most of this debt takes the form of bank loans. Banks were much larger than manufacturing firms. They had average stock-market value of about 122.1 million Mark.

On average, the accounting profit of a firm is about 503,000 Mark and 7,874,000 Mark for manufacturing and banks, respectively. The contracts of executives typically did not refer to these accounting profits as the basis for the calculation of bonus payments. Instead, the contracts referred to an "excess profit", which was the accounting profit minus a "guaranteed" return on the paid-up share capital as a threshold performance. On average, these excess profits amount to approximately 298,000 Mark for manufacturing firms and came to 3.74 million Mark for banks. Of these excess profits, each executive of a manufacturing firm received an

23 All data are deflated to 1913 prices using Hoffmann's (1965) NNP deflator. For comparison, one should note that per capita income in 1913 was about 800 Mark in Germany.

24 We measure Tobin's Q as the sum of equities at market value and liabilities at book value, divided by the book value of all assets. 
average annual bonus of about 11,900 Mark, whereas an executive of a bank received a bonus of nearly 145,300 Mark. $^{25}$

Regularly, a bonus was only paid if at least the threshold performance was met. In manufacturing, we observe 102 cases in which excess profits are negative, i.e., the threshold performance has not been met. In 50 per cent of these cases, no bonus is paid to the executives. Of the 702 cases in which the threshold performance is met, only 27.8 per cent report no bonus payment. For banking, these numbers are even more striking. If the threshold performance is not met, no bonus is paid in 86 per cent of the cases, whereas no bonus is paid in only 2 per cent of the cases where the threshold performance is met.

The number of executives varies between banks and manufacturing firms, reflecting the difference in size as well. The typical manufacturing firm has two executives, whereas a bank typically has five executive board members. Of particular interest are those manufacturing firms that have a single executive. If the board of executives consists of more than one person, we only have information about the average payment to all members of the board. If the board consists of only of a single CEO, however, we observe the actual bonus payment of this CEO. Consequently, we can check for the robustness of our findings to compositional considerations on the basis of this sub-sample. Compared to the whole sample, on average, single manager firms are smaller regardless of whether they were measured by their value of fixed assets (3.5 vs. 4.5 million Mark) or their stock market capitalization (5.2 vs. 7.3 million Mark). They were less strongly leveraged (27 per cent vs. 34 per cent) but paid a somewhat larger bonus to the executive (15,000 vs. 11,900 Mark).

As discussed in the previous section, one element of the reform act in 1884 was the reduction of restrictions on voting rights. Indeed, the fraction of companies that had some kind of voting restrictions in their charter decreased tremendously after 1884. In our sample, almost all manufacturing firms restricted voting rights in their charter before 1884 (94.7 per cent of all observations of manufacturing firms, 59.6 per cent for banks). By contrast, voting restrictions are much less common after the reform. Only in 36.9 per cent of all company years for manufacturing firms (and in 25.9 per cent for banking) does the charter restrict voting.

25 The bonus paid to an average executive was substantial. The average per capita income between 1871 and 1913 was 591 Mark (in 1913 prices). Therefore, executives of manufacturing firms received about 20 times the per capita income as a bonus; executives of banks received 246 times the per capita income as a bonus. These numbers are within the range of modern UK and US data (Conyon and Murphy, 2000), where the ratio of median incentive pay to per capita income is about 10 and 50, respectively, with larger incentive packages in the financial sector. 


\section{Estimation}

\subsection{Main results}

Our baseline specification is a random-effects Tobit model, where we employ the whole universe of manufacturing firms that is in our sample. We use all the data on these firms from 1870 until 1911. The random-effects Tobit specification captures the cross-sectional heterogeneity of the sample as well as the fact that a bonus paid to executives is non-negative by definition. The regression model thus is

$$
\mathrm{w}_{\mathrm{i}, \mathrm{t}}=\max \left(0, \alpha_{0}+\beta_{\tau 0} \pi_{\mathrm{i}, \mathrm{t}}+\left.\left(\beta_{\tau 1}-\beta_{\tau 0}\right) \pi_{\mathrm{i}, \mathrm{t}}\right|_{\mathrm{t} \in \tau 1}+\gamma \mathrm{x}_{\mathrm{i}, \mathrm{t}}+\mathrm{a}_{\mathrm{i}}+\mathrm{u}_{\mathrm{i}, \mathrm{t}}\right)
$$

where $\mathrm{w}_{\mathrm{i}, \mathrm{t}}$ is the average bonus paid to an executive of firm $\mathrm{i}$ at time $\mathrm{t}, \pi_{\mathrm{i}, \mathrm{t}}$ is excess profits, and $\mathrm{x}_{\mathrm{i}, \mathrm{t}}$ are other controls. Again, we opt for a linear instead of a logarithmic model for compensation for the same reason which we find the Tobit estimator appropriate for. There is a number of observations with zero bonuses (i.e. $\mathrm{w}_{\mathrm{it}}=0$ is a mass point). This not only makes a logarithmic specification unlikely as data-generating process, but it also means that taking logs we would aggravate the censoring problem to a problem of sample selection. Besides, as discussed before, Burhop (2004, 2005) finds by inspecting a number of actual executive contracts that the typical contract had indeed the above linear form.

Table 2 displays the results of this baseline specification, in which we also control for firm size and leverage. For manufacturing firms, an increase of excess profits of 1,000 Mark induced an additional bonus payment of about 46 Mark to each executive. ${ }^{26}$ As expected from our theoretical considerations, the 1884 reform decreased the profit share paid to each executive. After the reform, the marginal share of profits paid to executives is about 3.4 percentage points smaller than before the reform. This is captured in Table 2 by excess profits interacted with the dummy for the post-reform period. In other words, the 1884 joint-stock-companies reform act reduced the pay-performance sensitivity by nearly three-fourths. In turn, as an incentive, at least a profit share of 3.4 percentage points was given to each executive before 1884.

Two control variables are included in the baseline regression of the pay-performance sensitivity. First, the size of fixed assets was included since studies from modern Germany show a strong and positive correlation between firm size and executive compensation (e.g., Schwalbach and Graßhoff, 1997). This may be due to a more dispersed shareholder structure of lar-

26 These numbers lie well within range of the pay-performance sensitivities gathered by Burhop (2004, 2005) from the observation of actual contracts of German bank managers for the period 1854-1913. Moreover, using data from Burhop (2005), we investigated whether the base salary of executives changed abnormally after 1884. It turns out that the base salary of bank managers followed a positive linear trend with a negative level break in 1884. Unfortunately, information about base salaries is unavailable for manufacturing firms. Therefore, we cannot check the effect of the legal reform on base salaries. 
ger firms, which in turn leads to decreasing monitoring incentives. ${ }^{27}$ Second, the debt ratio is included as a control variable measuring the intensity of monitoring by debt holders (i.e., banks). ${ }^{28}$ From the two control variables, only the size of fixed assets has a significant impact on the bonus of the executives. The larger the assets, the fewer bonuses are paid (keeping profits constant). The debt ratio is statistically insignificant. Inspecting the parameter estimates for the constant and the post-1884 dummy, we see that the estimated bonus pay at average performance (defined for both sub-periods separately) is 3,780 Mark before 1884, with an increase after 1884 of 3,326 Mark. $^{29}$

Table 2: Pay-performance sensitivity - Baseline Regression Results

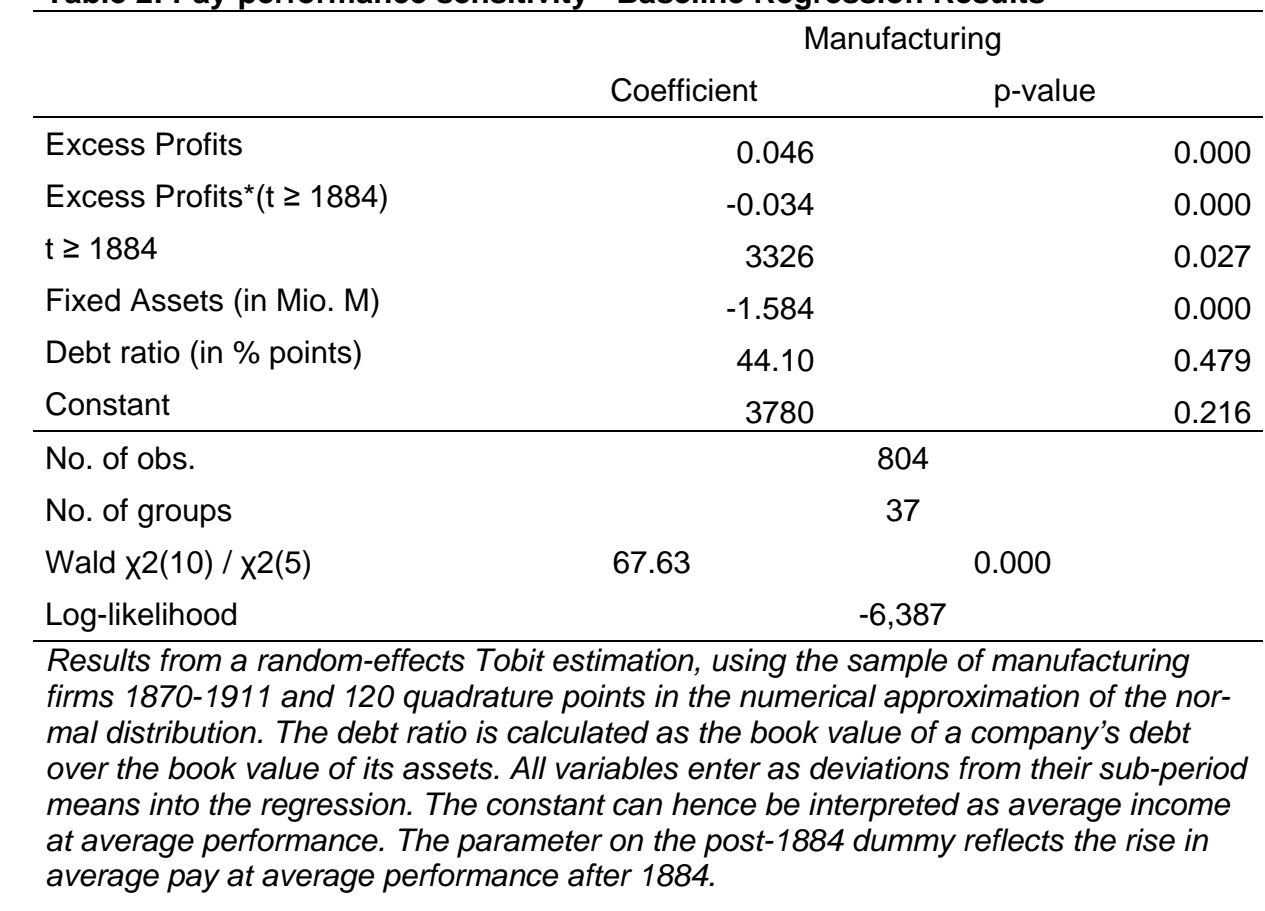

The reform enhanced other means of corporate control, e.g., the participation and voting rights of shareholders at the annual meeting, it increased accountability, and it reduced the set of allowed tasks for principals. This allowed principals to substitute incentive pay with other means, e.g., by laying off weakly performing managers (Bayer and Burhop, 2008). The remaining pay-performance sensitivity of 1.2 per cent reflects further incentive components of managerial contracts as well as all other factors that lead to a correlation of pay and performance, e.g., tight markets for managers in booms and loose markets for managers during busts.

27 The relevance of firm size for executive compensation is generally accepted. For example, Baker and Hall (2004) use differences in firm size to separate incentive components of executive compensation from non-incentive-related components.

28 For example, Neelam (2006) shows theoretically that a higher debt ratio can decrease the payperformance sensitivity.

29 All variables entered the regression as deviations from their sub-period means to allow for this interpretation of constants. 
To sum up, manufacturing firms paid bonuses related to the excess profits of the firms. The marginal claim of profits that went to the manager fell significantly after the implementation of better corporate governance institutions in 1884. This reform did not influence characteristics of managers, and the effect can therefore be interpreted as an incentive payment paid before the implementation of the new law. However, the non-performance-related element of bonuses increased somewhat after 1884 .

\subsection{Robustness tests}

We check for the robustness of our findings from this specification and complement it with five additional model estimations in this section. The first robustness check is to see whether the reform effect can be indeed attributed to an event in 1884 or just picks up a general trend in the managerial contracts. Second, we investigate whether the results found are specific to the manufacturing sector by using the data on banks that we have for comparison. Third, we check to see if our results are driven by compositional effects as the size of boards varies over time. For this reason we look at those firm years in which there is only a CEO and no other executives. Fourth, we check to see whether our results are sensitive to the assumption of homoscedasticity among the two sub-periods. For this purpose, we split the sample into two subperiods 1870-1884 and 1885-1911 and perform the estimation for both sub-samples separately. Finally, we check if restrictions of shareholders' voting rights or monitoring by bankers via the supervisory board matters for executive compensation. Qualitatively, our findings are robust to all five of these alternative specifications.

As a first robustness check we partition the time period 1888-1911 in seven 4-year intervals: 1888-1891,..,1904-1907, 1908-1911. We then include dummies and interaction terms with excess profits and for these sub-periods into the regression. This allows us to see whether there are systematic changes in the managerial compensation beyond the 1884 reform (i.e. further structural breaks). This robustness check can be understood in the spirit of placebo regressions in difference-in-difference estimation. If there was, for example, a general downward trend in the correlation of pay and performance, we may have falsely attributed this general trend to the reform in 1884 and hence to incentive pay in the pre-reform period. As one can see from Table 3, there is no such general trend. The correlation of pay and performance fluctuates after the reform, but these fluctuations are neither statistically nor economically significant. Most importantly, the estimated effect of the reform remains virtually unchanged corresponding to the fact that there is no general trend in performance pay after 1884 . That we find fluctuating coefficients of pay and performance is itself perfectly in line with the identification problem that motivates our research strategy. Performance and pay are correlated due to many factors, and some of these factors cannot be expected to be entirely constant over short periods time (e.g., cyclical demand fluctuations). 
Table 3: Pay-performance sensitivity (Robustness Check I) Controlling for trends in managerial compensation

\begin{tabular}{|c|c|c|}
\hline & \multicolumn{2}{|c|}{ Manufacturing } \\
\hline & Coefficient & $p$-value \\
\hline Excess Profits & 0.045 & 0.000 \\
\hline Excess Profits* $(t \geq 1884)$ & -0.033 & 0.000 \\
\hline$t \geq 1884$ & -154 & 0.941 \\
\hline $1888<t \leq 1892$ & -486 & 0.825 \\
\hline $1892<\mathrm{t} \leq 1896$ & 5 & 0.998 \\
\hline $1896<\mathrm{t} \leq 1900$ & 3706 & 0.081 \\
\hline $1900<\mathrm{t} \leq 1904$ & 7800 & 0.000 \\
\hline $1904<\mathrm{t} \leq 1908$ & 9744 & 0.000 \\
\hline $1908<t$ & 6067 & 0.012 \\
\hline Excess Profits ${ }^{\star}(1888<t \leq 1892)$ & 0.001 & 0.864 \\
\hline Excess Profits ${ }^{\star}(1892<\mathrm{t} \leq 1896)$ & -0.006 & 0.451 \\
\hline Excess Profits ${ }^{\star}(1896<t \leq 1900)$ & 0.001 & 0.841 \\
\hline Excess Profits ${ }^{\star}(1900<t \leq 1904)$ & 0.003 & 0.709 \\
\hline Excess Profits ${ }^{\star}(1904<\mathrm{t} \leq 1908)$ & -0.003 & 0.641 \\
\hline Excess Profits* $(1908<t)$ & -0.009 & 0.228 \\
\hline Fixed Assets (in Mio. M) & -1.788 & 0.000 \\
\hline Debt ratio (in \% points) & -23.881 & 0.711 \\
\hline Constant & 4044.045 & 0.156 \\
\hline No. of obs. & \multicolumn{2}{|c|}{804} \\
\hline No. of groups & \multicolumn{2}{|c|}{37} \\
\hline Wald X2(10) / x2(5) & 110.42 & 0.000 \\
\hline Log-likelihood & \multicolumn{2}{|c|}{-6368} \\
\hline \multicolumn{3}{|c|}{$\begin{array}{l}\text { Results from a random-effects Tobit estimation, using the sample of manufacturing } \\
\text { firms } 1870-1911 \text { and } 120 \text { quadrature points in the numerical approximation of the nor- } \\
\text { mal distribution. The debt ratio is calculated as the book value of a company's debt } \\
\text { over the book value of its assets. All variables enter as deviations from their sub-period } \\
\text { means into the regression. The constant can hence be interpreted as average income } \\
\text { at average performance. The parameter on the post-1884 dummy reflects the rise in } \\
\text { average pay at average performance after } 1884 \text {. }\end{array}$} \\
\hline
\end{tabular}

We believe a further splitting of the pre 1884 period does not make much sense due to the already small number of observations we have when pooling the period 1871-1883. However, we nonetheless experimented with such specification adding yet another possible structural break for 1880. This however yields no different conclusion. The only break that is significant is the one that separates the pre and the post 1884 period. $^{30}$

As a second robustness check, we look at the sample of data from the banking sector that we have collected for comparison. The results are displayed in Table 4. For banks, the pre-1884 bonus share in profits is 32 Mark for each executive per 1,000 Mark profit, and somewhat smaller than the pre-1884 profit share in manufacturing. The reform in 1884 has a qualitatively similar effect in the banking sector as in manufacturing. However, quantitatively the effect is just roughly one-third of the effect in the manufacturing sector. The post-1884 profit 
share that a manager received as a bonus is only 1.4 percentage points lower than before 1884. One explanation could be that banks had better corporate governance already before 1884, being reflected, for example, by the smaller percentage of voting restrictions in their charter. Moreover, banks are much larger in terms of total assets, stock market capitalization, and the number of executives. This is another reason that it is unlikely that the same quantitative effect of the reform will be seen.

Table 4: Pay-performance sensitivity (Robustness Checks II and III) Evidence from Banking and Single-Manager Firms

\begin{tabular}{|c|c|c|c|c|}
\hline & \multicolumn{2}{|l|}{ Banks } & \multicolumn{2}{|c|}{ Single-manager firms } \\
\hline & Coefficient & $p$-value & Coefficient & $p$-value \\
\hline Excess Profits & 0.032 & 0.000 & 0.040 & 0.001 \\
\hline Excess Profits ${ }^{\star}(t \geq 1884)$ & -0.014 & 0.001 & -0.023 & 0.054 \\
\hline$t \geq 1884$ & 132,146 & 0.000 & 5555 & 0.058 \\
\hline Fixed Assets & & & -1.40 & 0.155 \\
\hline Debt ratio & & & 3.11 & 0.002 \\
\hline Constant & 47,708 & 0.000 & 5901 & 0.132 \\
\hline No. of obs. & & 336 & & 318 \\
\hline No. of groups & & 9 & & 25 \\
\hline Wald X2(5) & 316.66 & 0.000 & 49.19 & 0.000 \\
\hline Log-likelihood & & $-3,869$ & & -2571 \\
\hline
\end{tabular}

Results from a random-effects Tobit estimation. using 120 quadrature points in the numerical approximation of the normal distribution. The debt ratio is calculated as the book value of a company's debt over the book value of its assets. Fixed Assets and debt are not available for banks. All variables enter into the regression as deviations from the averages of their sub-period and the respective group of companies. The constant can hence be interpreted as average income at average performance. The parameter on the post-1884 dummy reflects the rise in average pay at the average performance after 1884 .

Our third robustness check investigates whether the reform effect found may be due to changes in the composition of the executive board, in particular in the number of board members. We look separately at manufacturing firms managed by one executive only to account for the fact that we do not know the exact distribution of bonuses among board members. From our data, we know the total bonus payment to the whole executive board and the number of board members. We then assume that bonuses are distributed equally among executives. Still, it might be possible that one executive, the CEO, received a higher share in profits than other executives. In this case, changes in the composition of the board may be driving our results. To account for this, we construct a sub-sample of manufacturing firms managed by only one executive. About 40 per cent of our observations belong to this category. Our main result is that a significant influence of the 1884 legal reform on executive compensation is also visible in this sub-sample, yet at a lower level of significance. However, quantitatively the results are very close (see Table 4 ). 
Table 5: Pay-performance sensitivity (Robustness Check IV) Sample Split for the Sub-Periods 1870-1884 and 1885-1911

\begin{tabular}{|c|c|c|c|c|}
\hline & \multicolumn{2}{|c|}{ Pre-1884 observations } & \multicolumn{2}{|c|}{ Post-1884 observations } \\
\hline & Coefficient & $p$-value & Coefficient & $p$-value \\
\hline Excess Profits & 0.032 & 0.001 & 0.012 & 0.000 \\
\hline Fixed Assets & 0.614 & 0.568 & -1.464 & 0.000 \\
\hline Debt Ratio & -186 & 0.329 & 137 & 0.042 \\
\hline Constant & 4794 & 0.152 & 7213 & 0.011 \\
\hline No. of obs. & 132 & & 672 & \\
\hline No. of groups & 31 & & 36 & \\
\hline Wald X2(3) & 12.45 & 0.012 & 37.56 & 0.000 \\
\hline Log-likelihood & -976 & & $-5,393$ & \\
\hline
\end{tabular}

Our fourth robustness check splits the sample at the time of the reform. We compare the two sub-samples, i.e. all pre-1884 and all post-1884 observations for manufacturing firms, performing the regression analysis separately for both periods. Results are displayed in Table 5. This sample split tells us whether the assumption of homoscedasticity for both time periods may be crucial. The estimated relationship between excess profits and bonus payments aligns with the previous results. It is much larger in the pre-1884 period than after the corporate governance reform. The difference between the two point estimates is about 0.02 , which again is close to the effect measured by the dummy-variable approach used in the pooled regressions. However, the sample split allows us to observe other differences between the pre- and post1884 sub-samples. Company size does not influence bonus payments before the reform; but after 1884, we find a significantly negative relationship between the size of the fixed assets and the level of bonus payments. In view of the multi-tasking model of Holmstrom and Milgrom (1991), this can be interpreted as shareholders punishing the unwanted activity of empire-building. In addition, we reach a different conclusion with respect to the average pay at average performance than we do from the pooled estimation. Our sample split suggests average pay to have insignificantly decreased, and not to have increased, as we assumed before. 
Table 6: Pay-performance sensitivity (Robustness check V) Outside Control

\begin{tabular}{|c|c|c|}
\hline & \multicolumn{2}{|c|}{ Manufacturing } \\
\hline & Coefficient & $p$-value \\
\hline Excess Profits & 0.038 & 0.000 \\
\hline Excess Profits* $(t \geq 1884)$ & -0.025 & 0.005 \\
\hline$t \geq 1884$ & 638.36 & 0.763 \\
\hline Fixed Assets (in Mio. M) & -2.168 & 0.000 \\
\hline Debt ratio & 2.708 & 0.000 \\
\hline Voting Restriction * Excess Profits & -0.002 & 0.542 \\
\hline Voting Restriction & $-4,954$ & 0.006 \\
\hline Bank Supervision * Excess Profits & -0.011 & 0.003 \\
\hline Bank Supervision & $-3,373$ & 0.086 \\
\hline Constant & 10,428 & 0.000 \\
\hline No. of obs. & \multicolumn{2}{|l|}{797} \\
\hline No. of groups & \multicolumn{2}{|l|}{37} \\
\hline Wald X2(9) & 94.14 & 0.000 \\
\hline Log-likelihood & \multicolumn{2}{|c|}{$-6,432$} \\
\hline \multicolumn{3}{|c|}{$\begin{array}{l}\text { Results from a random-effects Tobit estimation, using the sample of manufactur- } \\
\text { ing firms } 1870-1911 \text { and } 120 \text { quadrature points in the numerical approximation } \\
\text { of the normal distribution. The debt ratio is calculated as the book value of a } \\
\text { company's debt over the book value of its assets. All non-dummy variables enter } \\
\text { as deviations from their sub-period means into the regression. 'Voting restric- } \\
\text { tions' is a dummy variable that takes the value } 1 \text { if the companies' charter devi- } \\
\text { ated in any way from the one-vote-per-share rule. 'Bank supervision' is a dummy } \\
\text { that takes the value one if the head of the supervisory board is a bank executive. }\end{array}$} \\
\hline
\end{tabular}

Finally, we check whether the outside control of executives by bank managers or the extent of shareholders' voting rights matter. From the corporate charter, we know whether the company deviated from the one-vote-per-share rule. Moreover, from the names of board members, we have information about whether the head of the supervisory board was an executive of a bank - if so, typically representing the corporations' largest creditor. We include this information into our regression analysis in forms of dummy variables and allow the pay-performance sensitivity to vary if there is bank supervision or if there are voting restrictions (see Table 6). It turns out that voting restrictions decrease the level of executive compensation, but did not influence the pay-performance sensitivity. On the other hand, bank supervision decreases the pay-performance sensitivity significantly. This may reflect that long-term relationship lenders curb managerial moral hazard and that bank representatives already before 1884 provided substantive monitoring which then also served as a substitute for monetary incentives of executives.

Compared to the effect of the reform in 1884, the effect of bank supervision is large; however, it is still significantly smaller than the reform effect itself. Moreover, bank supervision, as well as any restriction of voting rights, may be endogenous, which means we cannot give the parameter estimates a structural interpretation - unlike the effect of the reform in 1884, which we can interpret structurally. 


\subsection{Real Effects}

So far our focus has been on the contractual effects of an exogenous change in the code of corporate governance. While this is the aspect of our interest in this paper, this is but one possible focus on the effect of a legal reform of corporate governance. Lately the literature has highlighted the importance of corporate governance for the performance of companies. Gompers et al. (2003) have figured out that during the 1990s firms with stronger shareholder rights had a higher firm value, higher sales growth, lower capital expenditure, and a better stockmarket performance. A general problem in this kind of analysis, just as for the analysis of the incentive-governance nexus, is the endogeneity of corporate governance. Core et al. (2006) show that the market was not surprised by the weak performance of firms with weak corporate governance. This implies that information about weak governance is reflected in share prices from the outset. Having this discussion in mind, one may wonder to what extent our reform example, which is an event outside the control of the corporation itself, would not allow us to identify the real effects of changes in corporate governance, since the reform is exogenous. Still it is hard to identify the real effects of the 1884 reform, since a lack of a control group that is not subject to reform makes it impossible to differentiate this from all other macroeconomic influences.

Nonetheless, we may consider average outcomes over the sub-periods as indicative. If we look at performance indicators in Table 6, we see that the return on assets, as well as the return on fixed assets, increased substantially after 1884, while becoming less volatile (both across firms and across years). Returns on assets increased from 5.4 per cent before the reform to 6.6 per cent after the reform. Returns on fixed assets were 9.3 per cent before the reform and 15.9 per cent after the reform, an increase of more than 70 per cent.

Similarly, Tobin's Q increases from slightly less than one to nearly 1.25, reflecting that the market expects stronger firm growth and/or a higher valuation of not balanced assets, e.g., the human capital of the management or the market power of a firm. Conversely, high growth expectations are reflected by lower dividend yields, which, however, become steadier. Moreover, companies pay out a larger fraction of their profits as dividends. 
Table 7: Real effects of the 1884 reform

\begin{tabular}{|c|c|c|c|c|}
\hline \multirow{2}{*}{ Variable } & \multicolumn{2}{|c|}{ Before 1884} & \multicolumn{2}{|c|}{ After 1884} \\
\hline & mean & std. dev. & mean & std. dev. \\
\hline Return on assets (in per cent) & 5.4 & 5.9 & 6.6 & 4.9 \\
\hline Return on fixed assets (in per cent) & 9.3 & 10.6 & 15.9 & 19.0 \\
\hline Tobin's Q & 0.98 & 0.33 & 1.25 & 0.39 \\
\hline Dividend yield (in per cent) & 5.9 & 3.0 & 5.1 & 2.1 \\
\hline $\begin{array}{l}\text { Payout ratio (dividend in per cent of accounting } \\
\text { profit) }\end{array}$ & 82.8 & 33.8 & 90.1 & 191.7 \\
\hline $\begin{array}{l}\text { Fraction of profits paid to supervisory board (in per } \\
\text { cent) (only positive profits) }\end{array}$ & 4.75 & 4.52 & 4.97 & 3.91 \\
\hline $\begin{array}{l}\text { Fraction of profits paid to both boards (in per cent) } \\
\text { (only positive profits) }\end{array}$ & 9.32 & 4.67 & 9.40 & 5.20 \\
\hline $\begin{array}{l}\text { Total bonus payments to supervisory board (in } \\
\text { Mark) }\end{array}$ & 20,463 & 29,080 & 33,675 & 40,862 \\
\hline Total bonus payments to both boards (in Mark) & 29,429 & 30,201 & 46,171 & 41,998 \\
\hline Number of observations & \multicolumn{2}{|c|}{132} & \multicolumn{2}{|c|}{672} \\
\hline
\end{tabular}

Against this better performance, one has to set the costs of increased monitoring activity. The only observable data on this are the bonus payments to managers and supervisory boards. We saw that bonus payments increased slightly for managers of firms with average performance. If we look at the fraction of profits paid out to the supervisory board, we see that this number remains virtually unchanged. However, in absolute numbers the total expenses on bonuses for the supervisory board went up by about 65 per cent, which, however, also reflects the increase in firm size and profits over time. The relative agency costs, i.e., the fraction of profits paid by the shareholders to the executive and the supervisory board, remained virtually unchanged by the legal reform at about 9.4 per cent of profits.

Jointly and severally, firm performance was superior in the post-1884 period. On the other hand, relative direct agency costs remained virtually unchanged after the reform. This finding cannot, however, be causally related to the reform of corporate law, because it may well reflect several other uncontrolled macro- as well as microeconomic changes.

\section{Conclusion}

In this paper, we have used a fundamental reform of the German corporate-governance code the 1884 joint-stock companies act - as an identification scheme for incentive contracts. Employing a difference estimation technique, we find that improving upon other means of corporate governance reduces the use of monetary incentives substantially. This holds true even if we control for other variables, such as the stock-market value, total assets, or the liabilities of a firm.

Before the reform in 1884, an increase in profits of 1,000 Mark led to an increase of bonus payments to an executive by about 32-47 Mark. This share of profits distributed to each manager, however, does not necessarily measure incentives for executives. The estimated coefficient also absorbs the correlation between pay and performance induced by other variables, 
e.g., business cycle effects. The applied estimation framework separates these other components from the incentive component of the correlation.

The reform of the German joint-stock-companies act in 1884 serves as reference point for our identification. This reform enhanced corporate governance institutions, but it did not change the characteristics of managers or the influence of the business cycle on the pay-performance nexus. Thus, any shift in the correlation between managerial compensation and firm performance can be interpreted as an incentive component under the old regime of corporate governance. This incentive component was substituted for by better institutions under the new system of corporate governance introduced in Germany in 1884.

In fact, for manufacturing firms, the estimated influence of profits on managerial compensation declined by about two-thirds after 1884. This result proves both qualitatively and quantitatively robust to alternative estimation approaches and sample splits. For a sample of banks the effect is quantitatively somewhat smaller, but also significant. The shift in the estimated effect of profits on managerial compensation can be attributed to the incentive component of managerial compensation packages before the reform. Better institutions in 1884 allowed for the substitution of the monetary component.

As for the post-reform period, we still find a significant sensitivity of pay to performance. Naturally, we cannot exactly differentiate between general equilibrium, business cycle, and incentive effects in this empirical pay-performance sensitivity for the years after 1884. Yet, the large impact of the 1884 reform itself indicates that a substantial proportion of the sensitivity of pay to performance is due to incentives also after 1884. The reform cannot be expected to have wiped out all problems of corporate control, but only a substantial fraction of them.

In the light of these results, one may be alarmed by the over-optimistic interpretation of the effects of increases in the pay-performance relation observed in the recent decades. It may be that contracts were written sub-optimally before. Our results, however, suggest that managerial contracts were formed as an optimal reaction to changes in the contractual environment already in the $19^{\text {th }}$ century. Most importantly, they highlight the interconnection of all elements of corporate governance, incentive pay being but one. 


\section{References}

Aggraval, Rajesh K. and Andrew A. Samwick (1999): “The other Side of the Trade-off: The Impact of Risk on Executive Compensation”, Journal of Political Economy, 107 (1), 65105.

Baker, George P., and Brian J. Hall (2004): “CEO Incentives and Firm Size”, Journal of Labor Economics, 22 (4), 767-798.

Baltzer, Markus (2007): “Der Berliner Kapitalmarkt nach der Reichsgründung 1871: Gründerzeit, internationale Finanzmarktintegration und der Einfluss der Makroökonomie”, LIT Verlag, Berlin.

Baskin, Jonathan B. (1988): “The Development of Corporate Financial Markets in Britain and the United States, 1600-1914: Overcoming Asymmetric Information”, Business History Review, 62 (2), 199-237.

Bayer, Christian, and Carsten Burhop (2008): "If only I could sack you! Management turnover and performance in great German Banks between 1874 and 1913”, Applied Economics Letters, forthcoming.

Bittner, Thomas (2005): "An event study of the Rhenish-Westphalian Coal Syndicate", European Review of Economic History”, 9, 337-364.

Bosenick, Alfred (1912): „Neudeutsche gemischte Bankwirtschaft - Ein Versuch zur Grundlegung des Bankwesens“, Volume 1, Schweizer Verlag, Munich.

Burhop, Carsten (2004): "Executive Remuneration and Firm Performance: The Case of Large German Banks, 1854 -1910”, Business History, 46(4), 525-43.

Burhop, Carsten (2005): “Die Vergütung des Führungspersonals deutscher Großbanken, 1871-1913”, Vierteljahrschrift für Sozial- und Wirtschaftsgeschichte, 92 (3), 281-300.

Chhaochharia, Vidhi and Yaniv Grinstein (2007): “Corporate Governance and Firm Value: The Impact of the 2002 Governance Rules”, Journal of Finance, 62, 1789-1825.

Cheffins, Brian R. (2001): “The metamorphosis of 'Germany Inc.': The case of executive pay”, American Journal of Comparative Law, 49, 497-539.

Conyon, Martin J. (1997): “Corporate Governance and Executive Compensation”, International Journal of Industrial Organization, 15, 493-509.

Conyon, Martin J. and Kevin J. Murphy (2000): “The Prince and the Pauper? CEO Pay in the United States and the United Kingdom”, Economic Journal, 110, F640-671. 
Core, John E., Robert W. Holthausen, and David F. Larcker (1999): “Corporate Governance, Chief Executive Officer Compensation, and Firm Performance”, Journal of Financial Economics, 51, 371-406.

Core, John, Wayne R. Guay, and David F. Larcker (2003): "Executive Compensation and Incentives: A Survey”, Federal Reserve Bank New York Policy Review April 2003, $27-$ 50 .

Core, John, Wayne R. Guay, and Tjomme O. Rusticus (2006): “Does weak governance cause weak stock returns? An examination of firm operating performance and Investors' expectations”, Journal of Finance, 61 (2), 655-687.

Cuñat, Vicente, and Maria Guadalupe (2005): "How Does Product Market Competition Shape Incentive Contracts?", Journal of the European Economic Association, 3(5), 1058-1082.

Deutscher Reichstag (1873): "Stenographische Berichte über die Verhandlungen des Deutschen Reichstags, 1. Legislaturperiode, 4. Session, Band 1, 15. Sitzung”, Verlag der Buchdruckerei der Norddeutschen Allgemeinen Zeitung, Berlin.

Deutscher Reichstag (1884): "Stenographische Berichte über die Verhandlungen des Deutschen Reichstags, 5. Legislaturperiode, 4. Session, Vol. 3, Anlage 21”, Julius Sittenfeld, Berlin.

Edwards, Jeremy, and Sheilagh Ogilvie (1996): Edwards, Jeremy, and Sheilagh Ogilvie (1996): "Universal Banks and German Industrialization: A Reappraisal", Economic History Review, 49 (3), 427-446.

Elston, Julie Ann \& Goldberg, Lawrence G., (2003): "Executive compensation and agency costs in Germany," Journal of Banking and Finance, 27(7), 1391-1410.

Engel, Ernst (1875): "Die erwerbsthätigen juristischen Personen im preußischen Staate, insbesondere die Actiengesellschaften”, Zeitschrift des königlich-preußischen Statistischen Bureaus, 15, 449-536.

Fear, Jeffrey, and Christopher Kobrak (2006): "Diverging Paths: Accounting for Corporate Governance in America and Germany" Business History Review, 80(1), 1-44.

Fohlin, Caroline (1998): "Relationship Banking, Liquidity, and Investment in the German Industrialization", Journal of Finance, 53, 1737-1758.

Gareis, Karl (1880): „Das deutsche Handelsrecht: ein kurzgefaßtes Lehrbuch des im deutschen Reiche geltenden Handels-, Wechsel- und Seerechts“, Guttentag, Berlin.

Garen, John E. (1994): “Executive Compensation and Principal Agent Theory”, Journal of Political Economy, 102 (6), 1175-99. 
Girma, Sourafel, Steve Thompson, and Peter W. Wright (2007): “Corporate Governance Reforms and Executive Compensation Determination: Evidence from the UK”, Manchester School, 75 (1), 65-81.

Glagau, Otto (1877): „Der Börsen- und Gründungsschwindel in Deutschland“, Verlag von Paul Frohberg, Leipzig.

Goldman, Eitan, and Steve Slezak (2006): "An Equilibrium Model of Incentive Contracts in the Presence of Information Manipulation", Journal of Financial Economics, 80 (3), 603-626.

Gompers, Paul, Joy Ishii, and Andrew Metrick (2003): “Corporate Governance and Equity Prices”, Quarterly Journal of Economics, 118 (1), 107-155.

Grandy, Christopher (1989): "New Jersey Corporate Chartermongering, 1875-1929", Journal of Economic History, 49(3), 677-692.

Grossmann, Volker (2003): "Managerial job assignment and imperfect competition in asymmetric equilibrium”, IZA Discussion Paper 955, Institute for the Study of Labor.

Hall, Brian J. and Jeffrey B. Liebmann (1998) “Are CEOs really paid like bureaucrats?”, Quarterly Journal of Economics, 113 (3), 653-91.

Hart, Oliver (1995): “Corporate Governance: Some theory and implications”, Economic Journal, 105, 678-689.

Hessberger, Karl (1889): "Die volkswirtschaftlichen Wirkungen der Aktiengesetznovelle vom 18. Juli 1884 auf die Gründungen von Aktiengesellschaften", Fulda.

Himmelberg, Charles P. and Glenn Hubbard (2000): "Incentive Pay and the market for CEOs: An Analysis of Pay-for-Performance Sensitivity”, Columbia Business School Working Paper.

Holmstrom, Bengt and Paul Milgrom (1991): „Multitask Principal-Agent Analyses: Incentive Contracts, Asset Ownership, and Job Design“, Journal of Law, Economics, and Organization, 7, Special Issue, 24-52.

Hoffmann, Walther G. (1965): "Das Wachstum der deutschen Wirtschaft seit der Mitte des 19. Jahrhunderts”, Springer, Berlin.

Jensen, Michael C. and Kevin J. Murphy (1990): "Performance Pay and Top-Management Incentives”, Journal of Political Economy, 98 (2), 225-64.

Joskow, Paul L., Nancy L. Rose, and Catherine D. Wolfram (1996): "Political constraints on executive compensation: evidence from the electric utility industry", 27(1), 165-82. 
Kraft, Kornelius and Antonia Niederprüm (1999a): „Ist die Vergütung von Managern im Zeitablauf flexibler geworden?“, Zeitschrift für betriebswirtschaftliche Forschung, 51, 1999, 787 - 804.

Kraft, Kornelius and Antonia Niederprüm (1999b): "Determinants of management compensation with risk-averse agents and dispersed ownership firm”, Journal of Economic Behavior and Organization, 1999, 17-27.

Lazear, Edward P. (1986): “Salaries and piece rates”, Journal of Business, 59 (3), 405-431.

Lazear, Edward P. (2000): “The future of personnel economics”, Economic Journal, 110, F611-F639.

Litvak, Kate (2007): „The effect of the Sarbanex-Oxley act on non-US companies cross-listed in the US“, Journal of Corporate Finance, 13, 195-228.

Makower, H. (1877): „Das allgemeine Deutsche Handelsgesetzbuch nebst dem Preußischen Einführungsgesetze vom 24. Juni 1861 und der Instruktion vom 12. Dez. 1861”, Guttentag, Berlin.

Matthews, D., M. Anderson, and J.R. Edwards (1997): "The rise of the professional accountant in British business management", Economic History Review, 50 (3), 407-29.

Milward, Robert (2004): "European governments and the infrastructure industries, c. 18401914", European Review of Economic History, 8, 1-28

Murphy, Kevin J. (1999): “Executive Compensation”, In: Orley Ashenfelter and David Card (eds.): Handbook of Labor Economics, Vol. 3B, North-Holland, Amsterdam, 24852563.

Neelam, Jain (2006): “Debt, managerial compensation and learing”, European Economic Review, 50, 377-399.

Oechelhaeuser, Wilhelm (1876): “Die wirthschaftliche Krisis”, Springer, Berlin.

Oechelhaeuser, Wilhelm (1878): "Die Nachtheile des Aktienwesens und die Reform der Aktiengesetzgebung”, Springer, Berlin.

Peters, Lon LeRoy (1989): "Managing competition in German coal, 1893-1913", Journal of Economic History, 49, 419-434

Petrazickij, Lev I. (1906): „Aktienwesen und Spekulation“, Müller, Berlin.

Philippovich, Eugen von (1909): „Grundrißder politischen Ökonomie“, Volume 2, Part 1, 4th Edition, J.C.B. Mohr, Tübingen. 
Prendergast, Canice (1999): "The Provision of Incentives in Firms", Journal of Economic Literature, 37(1), 7-63.

Reitmayer, Morten (1999): „Bankiers im Kaiserreich“, Vandenhoeck \& Ruprecht, Göttingen.

Renaud, Achilles (1875): „Das Recht der Actiengesellschaften“, Tauchnitz, Leipzig.

Rettig, Rudi (1978): „Das Investitions- und Finanzierungsverhalten deutscher Grossunternehmen 1880-1911“, unpublished Ph.D. thesis, Münster.

Schwalbach, Joachim and Ulrike Graßhoff (1997): „Managervergütung und Unternehmenserfolg“, Zeitschrift für Betriebswirtschaftslehre, 67, 1997, 203 -217.

Shleifer, Andrei and Robert W. Vishny (1997): “A Survey of Corporate Governance”, Journal of Finance, 52 (2), 737-783.

Talley, Eric L. and Johnson Gudrun (2004): "Corporate Governance, Executive Compensation, and Securities Litigation", USC CLEO Research Paper No. C04-4.

Taylor, James: "Creating capitalism: Joint-stock enterprise in British politics and culture, 1800-1870”, Boydell \& Brewer, Woodbridge.

Tilly, Richard H. (1989): "Banking institutions in historical and comparative perspective: Germany, Great Britain and the United States in the nineteenth and early twentieth century”, Journal of Institutional and Theoretical Economics, 145(1), 189-209.

Tirole, Jean (2001): “Corporate governance”, Econometria, 69 (1), 1-35.

Tirole, Jean (2006): “The theory of corporate finance”, Princeton University Press, Princeton.

Van der Borght, Richard (1883): "Statistische Studien über die Bewährung der Actiengesellschaft”, Verlag von Gustav Fischer, Jena.

Warschauer, Otto (1902): „Die Reorganisation des Aufsichtsratswesens in Deutschland“, Freier Verlag, Berlin.

Witoki, M. Babajide (2007): „Corporate boards and regulation: The effect of the SarbanesOxley Act and the exchange listing requirements on firm value“, Journal of Corporate Finance, 13, 229-250. 